\title{
Institutional Credit of Agricultural (Extent of Repayment, Over Dues and Factors Responsible for Over Dues) - Study with Reference in the State of Rajasthan
}

\author{
Dr. Vishnu Shanker Meena ${ }^{1}$, Dr. S S Jheeba ${ }^{2}$ \\ ${ }^{1}$ Agricultural Economic Research Center, (Delhi School of Economics Campus) University of Delhi-110007 \\ ${ }^{2}$ Associate Professor, Department of Agricultural Economics, S.K.N. University of Agriculture, Jobner (Jaipur)-303 329
}

\begin{abstract}
The overall scenario of the sampled farmers in the state of Rajasthan reveals that the total costs of obtaining credit borne by the farmer borrowers is Rs.2290.28 in which Rs. 904.27 was spent on personal visits made by the farmer for obtaining credit, Rs. 676.00 on on getting various records involved in the processing the credit and Rs. 668.03 was paid to the bank during the processing of credit. The study shows that out of 160 sampled borrowers, 72 borrowers used their credit completely, 32 went for complete diversion of credit and rest utilized their credit partially. The repayment performance indicates that only 87.77 per cent of short-term credit, 83.05 per cent of medium-term credit and 74.40 per cent of long-term credit borrowed from the banks was repaid by due date and the remaining was over dues as on the due date. The regression results show that non-farm income, farm income and cropping intensity affected amount of overdue negatively while amount spent on un-productive purposes, old debts, amount borrowed and expenditure on family consumption had positive impact on the amount of overdue of sampled farmers. The major problems faced by the farmers while delaying with these agencies included inadequate loan amount, insufficient time for repayment, cost of borrowing, lack of knowledge of bank's formalities and lack of technical guidance. Prevalence of corrupt practices and non-cooperation from banking officials are major structural constraints in procurement of credit in mentioned districts. A major infrastructural bottleneck in the study areas is insufficient credit agencies that lead to low scale of finance in the study area.
\end{abstract}

Keywords: Credit extent of repayment, over dues,

\section{Introduction}

India is an agricultural country and since an average Indian farmer is a poor cultivator having his unit of land below one hectare, he always lives in a state of confusion for the agricultural production in his field. Agriculture provides raw material to various industries and has a potential to earn foreign exchange. The development of agriculture mainly depends upon the value of inputs and the proper utilization of the inputs by the farmers and through adoption of improved technology. The farmer is always in need of working capital and cash in hand for improved farming. The normal saving pattern of the Indian farmer is such that he cannot earn any capital gain on his investment in the farm. Credit thus has become a highly essential aspect for mobilizing agricultural development and breaking the vicious circle. It is therefore an essential part of farming that the farmers must be provided financial assistance by the Indian government through the banking system viz., commercial banks, cooperative banks/societies, land development banks, schedule banks etc. However, leading commercial banks kept themselves aloof from financial need of agriculture sector and were alleged of not performing proper role in planned national development. Hence, in 1969 the government of India decided the nationalization of banks. After nationalization of banks, the credit system was improved and loan facilities Determinants of farm credit utilization by farmers M.V. KHODKE, N.D. DESHMUKH AND N.B. MANE were provided by the banks. The credit provided through these banks is given in the form of different types of loan schemes like Kisan Gold Card, Krishi
Plus etc. which help for the cultivation of crops, purchase of livestock, development of dairy industries, development of irrigation and farm mechanization etc. In present investigation, efforts have been made to know the profile of loan borrower farmers, loan utilization pattern of borrower farmers and to find out relationship between characteristics of loan borrower farmers and the farm credit utilization pattern. This study aims to investigate the matters related to costs incurred by the farmer borrowers in obtaining the credit, utilization of the borrowed funds, its repayment, extent of overdues, the factors affecting it (overdues) and the types of problems faced by the farmer borrowers and the banking institutions in loaning process. Further, the working of financial institutions is not free from governmental and political influences. In addition, majority of the farmer borrowers are illiterate and are unaware of the loaning procedure and, therefore, easily fall prey to middlemen or commission agents, thereby increasing the cost of credit and reducing the amount of credit.

\section{Objectives}

This study endeavors to bridge the research gap in literature by covering following issues related to agricultural institutional credit:

- To calculate the extent of repayment, over dues,

- Factors influencing the over-dues in order, 


\section{International Journal of Science and Research (IJSR) \\ ISSN (Online): 2319-7064}

Index Copernicus Value (2015): 78.96 | Impact Factor (2015): 6.391

\section{Methodology}

The study was conducted in the state of Rajasthan. Jaipur region was selected purposively because the total credit flow for priority as well as agriculture sector by the institutional agencies was highest in Jaipur region out off in Jaipur and Siker district were selected purposively because the total credit flow for priority as well as agriculture sector by the institutional agencies were highest in these two districts of Rajasthan The primary as well as secondary data were use for present study. The secondary data were collected from lead bank of the selected district. The meaningful time series data for 10 year from 2000-01 to 2010-11 were collected. 11 were collected on expansion of intuitional credit to agriculture, repayment and over dues.

For the collection of primary data, a sample of 160 farmers (borrowers and equal number of non-borrowers) was randomly selected with probability proportion to number of farmers. Table 1 shows the distribution of total number of farmers of different size groups and selected farmers.

Table 1: Detail of farmers selection in different size groups in Rajasthan (Number)

\begin{tabular}{|l|c|c|c|c|c|c|}
\hline \multirow{2}{*}{ Size of group } & \multicolumn{2}{|c|}{ Jaipur } & \multicolumn{2}{|c|}{ Sikar } & \multirow{2}{*}{ Total } & \multirow{2}{*}{ Selected } \\
\cline { 2 - 6 } & No. of farmers & No. of selected farmers & No. of farmers & No. of selected farmers & & \\
\hline Marginal & 34 & 16 & 31 & 15 & 65 & 31 \\
\hline Small & 39 & 18 & 46 & 21 & 85 & 39 \\
\hline Semi-medium & 45 & 21 & 43 & 19 & 88 & 40 \\
\hline Medium & 31 & 15 & 34 & 16 & 65 & 31 \\
\hline Large & 21 & 10 & 22 & 9 & 43 & 19 \\
\hline Total & 170 & 80 & 176 & 80 & 346 & 160 \\
\hline
\end{tabular}

Extent of repayment, over dues and factors responsible for over dues

On the basis of repayment performance, the farmer borrowers were classified into three categories viz.,

(i) Non-defaulters

The farmer borrowers who repaid their loan instalments regularly on or before the due date were called as nondefaulters.

\section{(ii) Defaulters}

The farmer borrowers who failed to repay some or all of the regular instalments of loan by the due date were considered as defaulters.

The amount of credit repayable but not repaid on or before due date to the lending agency by the farmer borrowers was considered as loan overdues. It was calculated as:

$$
\mathrm{O}=\mathrm{A}+\mathrm{B}-\mathrm{C}
$$

Where,

$\mathrm{O}=$ Loan overdues

$\mathrm{A}=$ Amount to be paid during the year

$\mathrm{B}=$ Amount overdue at the beginning of the year

$\mathrm{C}=$ Amount actually paid during the year

The extent of overdues was calculated as :

$$
\begin{aligned}
& \text { Extent of overdues }(\%)=\frac{\text { Amount overdue }}{\text { Amount due for repayment }} \times 100 \\
& \text { Repayment performance }(\%)=\frac{\text { Amount repaid }}{\text { Amount due for repayment }} \times 100
\end{aligned}
$$

Factors response overdues

To understand the relative importance of various factors responsible for over-dues following functional analysis was used as the analytical tool:

\section{(a) Form of regression model}

Both linear and log linear forms of regression model were used to assess the effect of the factors / variables responsible for over-dues among the farmer borrowers. Form of the regression model was selected on the basis of statistical significance of the selected variables and goodness of fit. (b) Selection of the variables and their definitions Overdues are affected by a large number of factors depending upon the climatic, socio-economic and political environment in which the farmer borrowers perform. However, all the factors cannot be taken into account due to a variety of reasons like non-availability of desired data, multicollinearity among the explanatory variables, problems in their quantification, etc. To get rid of such problems only a few but most probable variables are taken into account. In the present investigation, based on theoretical a priori reasons, the following variables were selected to study their impact on overdues : (a) gross farm income, (b) non-farm income, (c) amount borrowed, (d) cropping intensity, (e) repayment capacity, (f) amount put to productive purposes, (g) amount put to un-productive purposes, (h) expenditures on family consumption (i) farm expenses (j) total land holdings, and (k) old debts. The variables included in the model are defined as follows:

\section{(i) Overdues (Y)}

The amount of loan repayable but not repaid on or before due date to the creditor was considered as over dues. This variables was taken as dependent variable of the regression model and was measured in money terms.

\section{(ii) Gross Farm Income $\left(\mathrm{X}_{1}\right)$}

Gross farm income was defined as the value of main and byproducts of crops and livestock. It was expressed in money terms and was included as an independent variable in the function.

\section{(iii) Non-farm Income $\left(\mathbf{X}_{2}\right)$}

Non-farm income (in `) was obtained by adding all types of incomes generated from off-farm activities.

\section{(iv) Amount Borrowed ( $\left.\mathbf{X}_{3}\right)$}

Amount of credit received by the farmer borrowers from various lending agencies both in cash and kind was added in monetary terms to arrive at amount borrowed. It was also taken as independent variable for functional analysis. 


\section{International Journal of Science and Research (IJSR) \\ ISSN (Online): 2319-7064 \\ Index Copernicus Value (2015): 78.96 | Impact Factor (2015): 6.391}

(v) Cropping Intensity $\left(\mathbf{X}_{4}\right)$

The extent of land use for cropping purpose during a given year was defined as cropping intensity and was expressed in percentage terms.

\section{(vi) Repayment Capacity $\left(\mathbf{X}_{5}\right)$}

The amount of credit left with the farmer borrower after meeting his farm and family needs and obligations to repay the loan was taken as repayment capacity.

\section{(vii) Amount Put to Productive Purposes $\left(\mathbf{X}_{6}\right)$}

The amount of credit that was used for stipulated as well as for other productive purposes was included in this variable.

\section{(viii) Amount Put to Un-productive Purposes $\left(\mathbf{X}_{7}\right)$}

It included the amount of loan diverted to un-productive purposes like domestic consumption, repayment of old debts, medical care, social ceremonies, etc.

\section{(ix) Expenditures on Family Consumption $\left(\mathbf{X}_{8}\right)$}

The consumption expenditures incurred on various items like food, health, education, clothing, recreation, social ceremonies, fuel and lighting, etc., as measured in monetary terms were considered as family consumption expenditures.

\section{(x) Farm Expenses $\left(\mathbf{X}_{\mathbf{9}}\right)$}

It included total expenditures incurred on various activities of livestock and crop production on the farm during the year. It was also measured in terms of money.

\section{(xi) Total Land Holding $\left(\mathbf{X}_{10}\right)$}

Total land holding means total operational holding, both irrigated and unirrigated, on the farms of farmer borrowers. It included rented in land but excluded rented out land.

\section{(xii) Old Debts $\left(\mathrm{X}_{11}\right)$}

Amount of previous (institutional) loan which was due for repayment in agricultural year 2010-11 were considered as old debts.

\section{Specification of the regression model for the study}

The factors affecting over dues of the farmer borrowers in the study area were identified by regressing over dues on the following explanatory variables:

Functional relationship

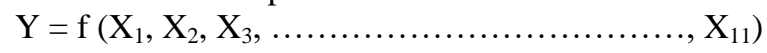

Where,

$\mathrm{Y}=$ Over dues (')

$\mathrm{X}_{1}=$ Gross farm income ()

$\mathrm{X}_{2}=$ Non-farm income ( $)$

$\mathrm{X}_{3}=$ Amount borrowed (')

$\mathrm{X}_{4}=$ Cropping intensity $(\%)$

$\mathrm{X}_{5}=$ Repayment capacity ( $)$

$\mathrm{X}_{6}=$ Amount put to productive purposes (')

$\mathrm{X}_{7}=$ Amount put to unproductive purposes ( $($ )

$\mathrm{X}_{8}=$ Expenditures on family consumption (')

$\mathrm{X}_{9}=$ Farm expenses ( ()

$\mathrm{X}_{10}=$ Total land holding (ha), and

$\mathrm{X}_{11}=$ Old debts ( $)$

Both linear and log-linear forms of the multiple regression

function as shown below were fitted to the data. (i) Multiple linear functional form

$$
\mathrm{Y}=\mathrm{a}+\mathrm{b}_{1} \mathrm{X}_{1}+\mathrm{b}_{2} \mathrm{X}_{2}+\mathrm{b}_{3} \mathrm{X}_{3}+\ldots \ldots .+\mathrm{b}_{11} \mathrm{X}_{11}+\mathrm{U}
$$

(ii) Multiple log-linear (Cobb-Douglas) functional form

$$
\mathrm{Y}=\mathrm{aX}_{1}^{\mathrm{b} 1} \mathrm{X}_{2}^{\mathrm{b} 2} \mathrm{X}_{3}^{\mathrm{b} 3} \ldots \ldots \ldots \ldots \ldots \mathrm{X}_{11}^{\mathrm{b} 11} 10^{\mathrm{U}}
$$

Which on log transformation takes the following form :

$\log Y=\log a+b_{1} \log X_{1}+b_{2} \log X_{2}+\ldots \ldots \ldots \ldots+b_{11}$ $\log \mathrm{X}_{11}+\mathrm{U}$

\section{(iii) Testing the Significance of Regression Coefficients}

The reliability of the regression coefficients $\left(b_{i}\right)$ was tested through the student's ' $t$ ' test of the form:

$$
t=\frac{b_{i}-\hat{b}_{i}}{S E\left(b_{i}\right)}
$$

Where,

$\mathrm{i}=0,1,2,3$----- $\mathrm{K}-1(\mathrm{~K}-$ being the total number of parameters estimated)

$\begin{array}{ll}\mathrm{t}= & \begin{array}{l}\text { The variable which follows the ' } \mathrm{t} \text { ' } \\ \text { distribution with }(\mathrm{n}-\mathrm{k}) \text { degrees of } \\ \text { freedom at chosen level of } \\ \text { significance } \\ \text { Estimates of the regression }\end{array} \\ \mathrm{b}_{\mathrm{i}} \quad \mathrm{marameter}\left(\mathrm{b}_{\mathrm{i}}\right) \text {; and } & \end{array}$

\section{$\ddot{\mathrm{SE}}\left(\mathrm{b}_{\mathrm{i}}\right)^{\wedge} \quad=\quad$ Standard error of the estimates}

For testing the reliability of $b_{i}$, it was hypothesized that there was no linear / log-linear relationship between the explanatory variable $\mathrm{X}_{\mathrm{i}}$ and the dependent variable $\mathrm{Y}$; i.e., $\mathrm{b}_{\mathrm{i} .}=0$

Symbolically it was denoted as $\mathrm{H}_{\mathrm{O}}: \mathrm{b}_{\mathrm{i}}=0$

To decide about the acceptance or rejection of null hypothesis, $\mathrm{H}_{\mathrm{O}}$ : $\mathrm{b}_{\mathrm{i}}=0$, vis-à-vis alternative hypothesis, $\mathrm{H}_{\mathrm{A}}$ $: b_{i} \neq 0$, the calculated value of ' $t$ ' was compared with the table value of ' $t$ ' for (n-k) degrees of freedom at $\alpha(\alpha=1 \%$, $5 \%$ and $10 \%$ ) level of significance which defined critical region for a two tailed test (a test in which the critical region lies on both the tails of the distribution curve, half area lying on each tail for a test of $\alpha$ level of significance).

The decision in regard to acceptance or rejection of the null hypothesis $\left(\mathrm{H}_{\mathrm{O}}, \mathrm{b}_{\mathrm{i}}=0\right)$ was made as follows:

(I) When the absolute value of the calculated ' $t$ ' was higher than the theoretical (tabulated) value of ' $t$ '; i.e., $|t|>t$, the null hypothesis was rejected.

(II) When $|t|<t$, the null hypothesis was not rejected in favour of the alternative hypothesis. In other words the $b_{i}$ was not considered statistically significant at chosen level of significance.

\section{Multicollinearity}

To test the presence of multicollinearity (high degree of correlation among the explanatory variables), simple correlation matrices as well as variance inflation factor (VIF) were worked out. For testing multicollinearity on the basis of correlation coefficients Klein's (1962) observation was taken in to consideration that the effect of multicollinearity was tolerable if the correlation between any pair of independent variables $\left(r_{i j}\right)$ included in the model did not exceed in magnitude to the multiple correlation 


\section{International Journal of Science and Research (IJSR) \\ ISSN (Online): 2319-7064 \\ Index Copernicus Value (2015): 78.96 | Impact Factor (2015): 6.391}

coefficient $(\mathrm{R})$ that is, $\left|\mathrm{r}_{\mathrm{ij}}\right|<|\mathrm{R}|$. Where $\mathrm{r}_{\mathrm{ij}}$ is the simple correlation coefficient between ith and jth variables.

For understanding the working out procedure for VIF consider the following linear model with $\mathrm{k}$ independent variables:

$Y=b_{0}+b_{1} X_{1}+b_{2} X_{2}+b_{j} X_{j}+\ldots \ldots \ldots \ldots+b_{k} X_{k}+e$

The standard error of the estiamte of $b_{j}$ is $\sigma\left(X^{\prime} X\right)^{-1} j+1, j+1$, where $X$ is regression design matrix - a matrix such that $\mathrm{X}_{\mathrm{i}, \mathrm{j}+1}$ is the value of the $\mathrm{j}^{\text {th }}$ covariate for the $\mathrm{i}^{\text {th }}$ case or observation, and $\mathrm{X}_{\mathrm{i}, 1}$ equals 1 for all $\mathrm{i}$. It turns out that this variance can be equivalently expressed as

$$
\operatorname{Var}\left(b_{i} \hat{)}=\frac{\sigma^{2}}{(n-1) \operatorname{vaf}\left(X_{i}\right)} \frac{1}{1-R_{i}^{2}}\right.
$$

Where,

$\mathrm{R}_{\mathrm{j}}{ }^{2}$ is the multiple $\mathrm{R}^{2}$ for the regression of $\mathrm{X}_{\mathrm{j}}$ on the other covariates (a regression that does not involve the response variable Y). This identity separates the influences of several distinct factors on the variance of the coefficient estimate:

$\sigma^{2}$ : Scatter in the data around the regression surface

n: Sample size

$\operatorname{Var}\left(\mathrm{X}_{\mathrm{j}}\right)$ : Variability in the covariates

The remaining term, $1 /\left(1-\mathrm{R}_{\mathrm{j}}{ }^{2}\right)$ is the VIF.

Calculation of VIF is done using following steps:

\section{Step one}

$\mathrm{K}$ number of VIFs (equal to the number of explaynatory variables) were calculated, one for each $\mathrm{X}_{\mathrm{i}}$ by first running an ordinary least square regression that had $X_{i}$ as a function of all the other explanatory variables in the first equation. If $i$ $=1$, for example, the equation would be

$$
\mathrm{X}_{1}=\propto_{2} \mathrm{X}_{2}+\propto_{3} \mathrm{X}_{3}+\ldots \ldots+\propto_{\mathrm{k}} \mathrm{X}_{\mathrm{k}}+\mathrm{C}_{0}+\mathrm{e}
$$

Where $c_{0}$ is a constant and $\mathrm{e}$ is the error term.

\section{Step two}

Then, the VIF factor for $b_{i}$ was calculated with the following formula:

$\operatorname{Var}\left(\mathrm{b}_{\mathrm{i}} \hat{)}=\frac{1}{1-\mathrm{R}_{\mathrm{i}}{ }^{2}}\right.$

Where $R_{i}^{2}$ is the coefficient of determination of the regression equation in step one.

\section{Step three}

Then, the magnitude of multicollinearity by considering the size of the VIF $\left(b_{i}\right)$ was analyzed. A common rule of thumb followed was that if VIF $\left(b_{i}\right)>10$ then, it was taken to near high multicollinearity (Kutner, 2004).

\section{Autocorrelation}

The term autocorrelation is defined as "correlation between members of series of observations ordered in time (as in time series data) or space (as in cross sectional data)". In the regression context the classical linear regression model assumes that such autocorrelation does not exist in the disturbances Ui. Symbolically, E (Ui Uj) $=0 \mathrm{i} \neq \mathrm{j}$. Violation of this assumption lead to the problem autocorrelation. Specification bias resulting from excluding some relevant variables from the model or using an incorrect functional form may lead to (spatial) autocorrelation in the cross sectional data. Although the OLS estimates remain unbiased as well as consistent in the presence of autocorrelation, they are no longer efficient. As a result, the usual ' $t$ ' and ' $F$ ' tests of significance cannot be applied legitimately. Hence remedial measures are needed depending upon the nature of interdependence among the disturbances Ui (William and Kendall, 1971). In the present investigation Durbin-Watson test (1951) was used to test the autocorrelation between the residuals. For testing autocorrelation Durbin - Watson'd' statistic was calculated as follows:

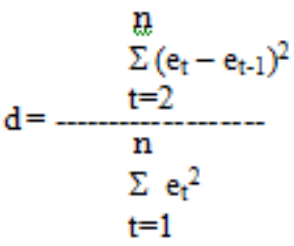

Where;

$e_{t}$ are sample residuals. The test for autocorrelation was conducted as follows:

$\mathrm{H}_{\mathrm{o}}: \rho=0 \quad \mathrm{H}_{\mathrm{A}}: \rho>0$ (Positive autocorrelation)

If ' $\mathrm{d}$ ' $<\mathrm{dL}$ rejected $\mathrm{H}_{\mathrm{o}}$ in favour of positive

autocorrelation

If $\mathrm{dL}<$ ' $\mathrm{d}$ ' $<\mathrm{du} \quad$ inconclusive

If $\mathrm{du}<$ ' $\mathrm{d}$ ' did not reject Ho

$\mathrm{H}_{\mathrm{O}}: \rho=0 \quad \mathrm{H}_{\mathrm{A}}: \rho<0$ (Negative autocorrelation)

If ' $\mathrm{d}$ ' $<4-\mathrm{du} \quad$ did not reject $\mathrm{H}_{\mathrm{O}}$

If $(4-d u)<$ 'd' $<$ (4-dL) inconclusive

If $(4-d L)<$ 'd' rejected $\mathrm{H}_{\mathrm{O}}$ in favour of negative

autocorrelation

Where;

$\mathrm{H}_{\mathrm{O}}=$ Null hypothesis

$\mathrm{H}_{\mathrm{A}}=$ Alternative hypothesis

$\rho=$ Autocorrelation coefficient

$\mathrm{d}=$ Durbin - Watson statistic

$\mathrm{dL}=$ Lower limit for the critical value

$\mathrm{du}=$ Upper limit for the critical value

The regions of acceptance and rejection of null hypothesis in Durbin-Watson test were depicted as below-

I $\quad 0-\mathrm{dL}$, i.e., $\quad 0<\mathrm{d}<\mathrm{dL}$ positive autocorrelation

II $\mathrm{dL}-\mathrm{du}$, i.e., $\mathrm{dL}<\mathrm{d}<\mathrm{du} \quad$ Inconclusive

III $d u-(4-d u)$, i.e., $d u<d<(4-d u) \quad$ No autocorrelation

IV (4-du)- (4-dL), i.e. , (4-du) $<\mathrm{d}<$ (4-dL) Inconclusive

V $(4-d L)-4$, i.e., $(4-d L)<d<4$ Negative autocorrelation

For testing autocorrelation following procedure was

followed.

1) From the Durbin-Watson tables the $\mathrm{dL}$ and $\mathrm{du}$ values were noted down for ' $\mathrm{n}$ ' number of observations, ' $\mathrm{K}$ ' number of explanatory variables excluding the constant term and required level of significance.

2) Then 'd' value was calculated from the sample errors.

3) Finally, the region in which the estimated value of 'd' lay was located and the inference was drawn in a manner as stated above.

\section{Estimation of elasticity}

The elasticity of overdues for linear relationship was computed as under;

$E\left(X_{i}\right)=\hat{b_{i}} \frac{\overline{X_{i}}}{\overline{Y_{i}}}$ 


\section{International Journal of Science and Research (IJSR) \\ ISSN (Online): 2319-7064 \\ Index Copernicus Value (2015): 78.96 | Impact Factor (2015): 6.391}

\section{Result and Discussion}

Agency-wise credit disbursement in state of Rajasthan. Agricultural credit flow is an important concept and now a necessity to facilitate better agricultural practices. The importance of agricultural credit can be learnt from the fact that it has been an important component of agricultural planning in India. Commercial Banks, Regional Rural Banks and Cooperative banks are the three important agencies disbursing agricultural credit in the state of Rajasthan. Table 1 reveals agency-wise credit disbursement in state of Rajasthan. The repayment performance of the farmer borrower was measured in terms of percentage of amount repaid to the amount due for repayment in the given period. Total repayable amount is equal to the principal amount along with the interest payment. The amount not paid on the due date is considered to be the overdue amount. The repayment and overdue across all size group is calculated separately for banks and cooperatives in the following section.

\section{Repayment performance and extent of overdue of bank credit}

In order to study the repayment performance and extent of overdue of bank credit for the sampled farmer borrowers in Rajasthan, it is important to study the short-term, mediumterm and long-term bank credit individually. Next three sections are devoted to the same.

\section{Short-term bank credit}

Table 1 revealed that total short-term credit borrowed by the sampled farmers in the state of Rajasthan is Rs. 3217.84 per hectare

In case of marginal farms, total per farm short-term credit amount borrowed from banks is Rs. 7234.19 per hectare. Rs. 5337.70 In case of per hectare average short-term credit borrowed, Rs. 7740.60 was repayable amount. Rs. 6661.90 per hectare was repaid out of the total repayable amount and the remaining amount was overdue.

On small farms, the total average repayable short-term credit borrowed amount is Rs. 4947.90 per hectare. Rs. 4360.00 per hectare was repaid and Rs. 587.00 per hectare was overdue out of total repayable amount. In case of semimedium farms, the average short-term credit repayable came to be Rs. 2796.20 per hectare. Rs. 2516.70 per hectare were repaid on due date while remaining amount existed as overdues for this category. On medium farms, the average total short-term credit repayable by the borrower farmers is Rs. 2729.50 per hectare. remained overdue. Rs. 2478.80 was repaid and Rs. 250.64 remained overdue in case of per hectare average short-term credit borrowed from banks. In large category of farms, , the total repayable short-term amount is Rs. 3697.70 per hectare out of which Rs. 3143.90 was repaid on due date. The extent of overdue was Rs. 553.81 per hectare in case of large farms.
Table 1: Per hectare average short-term credit borrowed from the banks, repaid and over dues thereof during - 201213 in Rajasthan

\begin{tabular}{|c|c|c|c|c|}
\hline \multirow{2}{*}{ Size of groups } & \multicolumn{4}{|c|}{ Amount } \\
\cline { 2 - 5 } & Borrowed & Repayable & Repaid & Overdue \\
\hline Marginal & 7234.19 & 7740.60 & 6661.90 & 1078.70 \\
\hline Small & 4624.20 & 4947.90 & 4360.90 & 587.00 \\
\hline Semi-medium & 2613.25 & 2796.20 & 2516.70 & 279.45 \\
\hline Medium & 2550.90 & 2729.50 & 2478.80 & 250.64 \\
\hline Large & 3455.75 & 3697.70 & 3143.90 & 553.81 \\
\hline Overall & 3217.84 & 3443.10 & 3023.00 & 420.13 \\
\hline
\end{tabular}

The total repayable average short term credit increased with an increase in operational holdings on per farm basis but contrary situation was observed on per hectare basis.

\section{Repayment performance and extent of overdue of co-} operatives

This section provides the details of per hectare short-term co-operative credit borrowed, repaid and the overdues for sampled farmers in the state of Rajasthan for kharif and rabi season. Firstly, we examine the same for Kharif season and the it is followed by the study on rabi season.

Short-term co-operative credit-kharif season

Table 2: Per hectare average short-term cooperative credit borrowed, repaid and overdue during kharif season 2010-11 in Rajasthan

\begin{tabular}{|c|c|c|c|c|}
\hline \multirow{2}{*}{$\begin{array}{c}\text { Size of } \\
\text { groups }\end{array}$} & \multicolumn{4}{|c|}{ Amount } \\
\cline { 2 - 5 } & Borrowed & $\begin{array}{c}\text { Repayable on } \\
\text { Feb. 28, 2011 }\end{array}$ & $\begin{array}{c}\text { Repaid upto } \\
\text { Feb. 28, 2011 }\end{array}$ & $\begin{array}{c}\text { Overdue on } \\
\text { March 1, 2011 }\end{array}$ \\
\hline Marginal & 8249.70 & 8538.40 & 7988.50 & 549.99 \\
\hline Small & 8333.67 & 8625.30 & 8345.40 & 279.96 \\
\hline $\begin{array}{c}\text { Semi- } \\
\text { medium }\end{array}$ & 6708.64 & 6943.40 & 6726.40 & 217.07 \\
\hline Medium & 4282.83 & 4432.70 & 4301.60 & 131.14 \\
\hline Large & 3381.96 & 3500.30 & 3418.00 & 82.37 \\
\hline Overall & 4964.50 & 5138.30 & 4980.00 & 158.22 \\
\hline
\end{tabular}

Table 2. indicates that repayment performance of farmer borrowers increased with an increased in farm size unlike in case of credit borrowed from banks.

\section{Short- term credit borrowed from cooperatives-rabi season}

The information per hectare repayable, repaid and overdue of short-term average credit borrowed from cooperatives during rabi season by the due date (up to $31^{\text {st }}$ may 2013) and its repayment performance are presented in table $\mathbf{3}$ respectively.

Table 3: Per hectare average short-term co-operative credit borrowed, repaid and overdue during Rabi season - 2012-13 in Rajasthan

\begin{tabular}{|c|c|c|c|c|}
\hline \multirow{2}{*}{$\begin{array}{c}\text { Size of } \\
\text { groups }\end{array}$} & \multicolumn{4}{|c|}{ Amount } \\
\cline { 2 - 5 } & Borrowed & $\begin{array}{c}\text { Repayable as } \\
\text { on May 31, } \\
2012\end{array}$ & $\begin{array}{c}\text { Repaid upto } \\
\text { May 31, } \\
2012\end{array}$ & $\begin{array}{c}\text { Overdue as } \\
\text { On June 1, } \\
2012\end{array}$ \\
\hline Marginal & 8455.49 & 8751.40 & 8083.90 & 667.50 \\
\hline Small & 8080.21 & 8363.00 & 8013.60 & 349.42 \\
\hline Semi-medium & 6634.92 & 6867.10 & 6666.10 & 201.05 \\
\hline Medium & 4603.98 & 4765.10 & 4650.60 & 114.47 \\
\hline Large & 4363.87 & 4516.60 & 4436.10 & 80.52 \\
\hline Overall & 5379.32 & 5567.60 & 5408.60 & 159.01 \\
\hline
\end{tabular}




\section{International Journal of Science and Research (IJSR) \\ ISSN (Online): 2319-7064 \\ Index Copernicus Value (2015): 78.96 | Impact Factor (2015): 6.391}

A perusal of Table 2 indicates that total per hectare repayable amount borrowed from cooperatives during rabi season by marginal farmers is Rs. 8751.40. The repaid amount on due date of marginal farmers was Rs. 8083.90. On small farms, the total average per hectare repayable amount borrowed from cooperatives during rabi season is Rs. 8363.00. Rs. 8013.60 was repaid on due date while amount of overdues was Rs. 349.42. In case of semi-medium farms, the average per hectare repayable amount borrowed from cooperatives during rabi season came to be Rs. 6867.10. Rs. 6666.10 was repaid on due date while the rest of the amount remained overdue in this category. On medium farms, the average total per hectare repayable amount borrowed from cooperatives during rabi season by the borrower farmers is Rs. 4765.10 out of which Rs. 4650.60 was repaid on due date while Rs. 114.47 remained overdue. In large category of farms, Rs. 4516.60 was the total repayable amount borrowed from cooperatives during rabi season out of which Rs. 4436.10 was repaid on due date. Overall analysis shows that per farm repayment performance increased with an increase in size of the operational holdings.

\section{Category wise defaulters and per defaulter overdue amount}

A category-wise defaulter and amount of overdue per defaulter for sampled farmer borrowers in the state of Rajasthan is presented in this section and the results are laid down in table 4 indicates that out of 160 borrowers, 73 borrowers were defaulter. Inter-category analysis indicates that share of marginal, small, semi-medium, medium and large borrowers in total number of borrowers was 19.38, $24.38,25.00,19.38$ and 11.88 per cent. Out of 73 defaulters, 19.18 per cent were marginal farmers, 17.81 per cent were small farmers, 26.03 per cent were semi-medium farmers, 23.29 per cent were medium farmers and 13.70 per cent were large farmers. Share of marginal farmers (42.33\%) in total amount of overdues was highest while marginal farmers had the lowest share $(4.47 \%)$. The amount of overdue per defaulter ranged between Rs. 6157.00 for marginal farmers to Rs. 71804.00 for large farmers. The overdue amount per defaulter increased with an increase in farm size.
Table 4: Category-wise defaulters and per defaulter overdues amount

\begin{tabular}{|l|c|c|c|c|}
\hline $\begin{array}{l}\text { Size } \\
\text { groups }\end{array}$ & $\begin{array}{c}\text { Total } \\
\text { number of } \\
\text { borrowers }\end{array}$ & $\begin{array}{c}\text { Total } \\
\text { number of } \\
\text { defaulters }\end{array}$ & $\begin{array}{c}\text { Total } \\
\text { amount of } \\
\text { overdues }\end{array}$ & $\begin{array}{c}\text { Overdue } \\
\text { amount per } \\
\text { defaulter }\end{array}$ \\
\hline Marginal & 31 & 14 & 129305 & 6157 \\
\hline Small & $(19.38)$ & $(19.18)$ & $(4.47)$ & $(3.69)$ \\
\hline & $(24.38)$ & $(17.81)$ & $(9.12)$ & $(7.53)$ \\
\hline $\begin{array}{l}\text { Semi- } \\
\text { medium }\end{array}$ & 40 & 19 & 558585 & 29399 \\
\hline & $(25.00)$ & $(26.03)$ & $(19.29)$ & $(17.60)$ \\
\hline Medium & 31 & 17 & 1225640 & 47140 \\
\hline & $(19.38)$ & $(23.29)$ & $(42.33)$ & $(28.21)$ \\
\hline Large & 19 & 10 & 718038 & 71804 \\
\hline & $(11.88)$ & $(13.70)$ & $(24.80)$ & $(42.98)$ \\
\hline Overall & 160 & 73 & 2895697 & 167077 \\
\hline & $(100.00)$ & $(100.00)$ & $(100.00)$ & $(100.00)$ \\
\hline
\end{tabular}

Figures in parentheses are the percentages by the total

\section{Regression Results}

The next section provides regression results for affects of different factors on overdue for marginal, small, semimedium, medium and large farms. Low values of VIF (10) for all explanatory variables across all categories in both the districts indicate that multicollinearity problem was absent for all the explanatory variables. The Durbin-Watson test statistic tests the null hypothesis that the residuals from an ordinary least-squares regression are not auto correlated. The Durbin-Watson statistic ranges in value from 0 to 4 . A value near 2 indicates non-autocorrelation; a value toward 0 indicates positive autocorrelation; a value toward 4 indicates negative autocorrelation. The tables for all farm sizes indicate that the value of $d$ ranged between 1.65 and 2.23 which is close to 2 indicating absence of any autocorrelation.

\section{Regression results for marginal farmer}

For marginal category of farmers, two most important factors that affect amount of overdue are non-farm income as marginal farms use labour services to earn extra income and on old debts that may be taken to meet requirements like social ceremonies, medical expenses, etc. the results are presented in Table 5D.12 for the sampled farmer borrowers.

Table 5

Estimated multiple linear regression model for the marginal farmer borrowers

Dependent variable - overdues (Y)

Number of farmer borrowers $(\mathrm{N})=20$

\begin{tabular}{|l|l|c|c|c|c|}
\hline S. No. & Explanatory variables & Regression coefficients & Standard Error & $V I F$ & Elasticity coefficients \\
\hline 1. & Intercept $(\mathrm{a})$ & 4868.1553 & 1258.5928 & - & - \\
\hline 2. & Non-farm income $\left(\mathrm{X}_{2}\right)$ & $-0.1156^{* *}$ & 0.0378 & 1.1322 & -0.86 \\
\hline 3. & Old debts $\left(\mathrm{X}_{11}\right)$ & $0.1751^{* * *}$ & 0.0277 & 1.1322 & 2.52 \\
\hline
\end{tabular}

$>$ Coefficient of determination $\left(\mathrm{R}^{2}\right) \quad-0.8448$

$>$ Adjusted coefficient of determination $\left(\mathrm{R}^{2}\right)-0.8209$

$>$ Coefficient of multiple correlation $(\mathrm{R}) \quad-0.9191$

$>$ 'd' statistics

$-1.9275$

$>$ ' $\mathrm{F}$ ' value (with 2,17 d.f.)

$-35.38$

*** Significant at $1 \%$ level of significance

** Significant at $5 \%$ level of significance

Regression results for marginal category of farmers indicate that regression coefficient of non-farm income $\left(X_{2}=-\right.$
0.1156) was significant at 5 per cent level of significance and the negative sign emphasizes that as the non-farm 


\section{International Journal of Science and Research (IJSR) \\ ISSN (Online): 2319-7064 \\ Index Copernicus Value (2015): 78.96 | Impact Factor (2015): 6.391}

income increased, farmers repaying capacity improved which in turn led to decline in overdues. The regression coefficient of old debts $\left(\mathrm{X}_{11}=0.1751\right)$ was significantly positive at 1 per cent level of significance indicating that as old debts increased, lower portion of income was left for repayment of debts and this led to an increase in overdue amount. Non-farm income and old debts explained 82.09 per cent of the variation in the amount of overdue for marginal farmers. The elasticity of coefficient that explained change in overdue per unit change in explanatory variable was -0.86 for non-farm income and 2.52 for old debts.

\section{Regression results for Small farmer}

For small category of farmers, factors that affect amount of overdue were calculated to be amount spent on unproductive purposes and old debts that were taken to meet the extra requirements of farmer borrowers. The results are presented in Table 5D.13.

Table 6

Estimated multiple linear regression model for the small farmer borrowers

Dependent variable - overdues (Y)

Number of farmer borrowers $(\mathrm{N})=21$

\begin{tabular}{|l|l|c|c|c|c|}
\hline S. No. & Explanatory variables & Regression coefficients & Standard Error & VIF & Elasticity coefficients \\
\hline 1. & Intercept $(\mathrm{a})$ & 4709.1642 & 2694.3461 & - & - \\
\hline 2. & Amount put to un-productive purposes $\left(\mathrm{X}_{7}\right)$ & $0.2732^{* * *}$ & 0.0376 & 1.4351 & 1.45 \\
\hline 3. & Old debts $\left(\mathrm{X}_{11}\right)$ & $0.2071^{*}$ & 0.0867 & 1.4351 & 0.31 \\
\hline
\end{tabular}

$>$ Coefficient of determination $\left(\mathrm{R}^{2}\right) \quad-0.8610$

$>$ Adjusted coefficient of determination $\left(\mathrm{R}^{2}\right)-0.8456$

$>$ Coefficient of multiple correlation (R) $\quad-0.9279$

$>$ 'd' statistics

$-1.6598$

$>$ ' $F$ ' value (with 2,18 d.f.)

$-55.76$

*** Significant at $1 \%$ level of significance

* Significant at $10 \%$ level of significance

Regression results for small category of farmers indicate that regression coefficient of amount put to un-productive purposes $\left(\mathrm{X}_{7}=0.2732\right)$ was significant at 1 per cent level of significance and the positive sign emphasizes that as the amount put to un-productive purposes increased, amount available for productive purposes declined leading to piling of overdue amount. The regression coefficient of old debts $\left(\mathrm{X}_{11}=0.2071\right)$ was significantly positive at 10 per cent level of significance indicating that an increase in old debts adversely affected the repaying capacity of farmer. Expenditures on family consumption and old debts explained 84.56 per cent of the variation in the amount of overdue for small farmers. The elasticity of coefficient for amount put to un-productive purposes was 1.45 explaining that one per cent change in of amount put to un-productive purposes led to 1.45 per cent change in overdue. The elasticity of coefficient for old debts was 0.31 .

\section{Regression results for Semi-medium farmer}

For semi-medium category of farmers, factors that affect amount of overdue are gross farm income, amount borrowed and amount put to un-productive purposes. Together they explained 93.46 percent of variation in amount of overdue. The results are presented in Table 5D.14.

Regression results for semi-medium category of farmers indicate that the regression coefficient of gross farm income $\left(\mathrm{X}_{8}=-0.0122\right)$ was significantly positive at 10 per cent level of significance and the negative sign emphasizes that as the gross farm income of the farmer increases, farmers repaying capacity increases which in turn led to decrease in overdues. The regression coefficient of amount borrowed $\left(\mathrm{X}_{3}=0.2541\right)$ was significant at 10 per cent level of significance and indicated that as higher amount borrowed by the farmer led to higher amount of overdue. Amount put to unproductive purposes with regression coefficient equivalent to 0.1457 at 10 per cent level of significance implied that increase in amount spent on un-productive purposes adversely affects the amount left to repay overdue with the farmer and hence led to piling up of overdue amount. The elasticity of coefficient that shows the change in overdue amount per unit change in explanatory variables was $0 .-1.26,2.35$ and 1.17 for gross farm income, amount borrowed and amount put to un-productive purposes, respectively.

Table 7: Estimated multiple linear regression model for the semi-medium farmer borrowers

Dependent variable - overdues (Y)

Number of farmer borrowers $(\mathrm{N})=19$

\begin{tabular}{|c|c|c|c|c|c|}
\hline S. No. & Explanatory variables & Regression coefficients & tandard Error & $V I F$ & Elasticity coefficients \\
\hline 1. & Intercept $(\mathrm{a})$ & 15191.9631 & 10816.2171 & - & - \\
\hline 2. & Gross farm income $\left(\mathrm{X}_{1}\right)$ & $-0.0122^{*}$ & 0.0533 & 1.0680 & -1.26 \\
\hline 3. & Amount borrowed $\left(\mathrm{X}_{3}\right)$ & $0.1457^{*}$ & 0.0497 & 7.2694 & 2.35 \\
\hline 4. & Amount put to un- productive purposes $\left(\mathrm{X}_{7}\right)$ & $0.2541^{*}$ & 0.0887 & 7.3368 & 1.17 \\
\hline
\end{tabular}

$>$ Coefficient of determination $\left(\mathrm{R}^{2}\right)$

$-0.9455$

$>$ Adjusted coefficient of determination $\left(\mathrm{R}^{2}\right)-0.9346$

$>$ Coefficient of multiple correlation $(\mathrm{R}) \quad-0.9724$

$>$ 'd' statistics

$>$ ' $F$ ' value (with 3,15 d.f.)

$-1.6468$

$-86.73$

* Significant at $10 \%$ level of significance 


\section{International Journal of Science and Research (IJSR) \\ ISSN (Online): 2319-7064 \\ Index Copernicus Value (2015): 78.96 | Impact Factor (2015): 6.391}

\section{Regression results for Medium farmer}

For medium category of farmers, amount borrowed; cropping intensity and old debts are important factors that affect amount of overdue. The results are presented in Table 5D. 15 .

Regression results for medium category of farmers of indicate that regression coefficient of amount borrowed $\left(\mathrm{X}_{5}=\right.$ 0.0844 ) was significant at 5 per cent level of significance and the positive sign emphasizes that increase in the amount borrowed led to an increase in debt liability on farmer borrowers. This in turn led to an increase in overdue amount as farmers have limited repaying capacity. The cropping intensity showed negative impact on amount of overdue as the value of regression coefficient was -0.3111 and it was significant at 10 per cent level of significance. The regression coefficient of old debts $\left(\mathrm{X}_{11}=0.4781\right)$ was significantly positive at 5 per cent level of significance indicating that an increase in old debts adversely affected the repaying capacity of farmer. The above mentioned factors, namely, amount borrowed, cropping intensity and old debts together explained 72.24 per cent of the variation in the amount of overdue for medium farmers. The elasticity of coefficient for amount borrowed was 2.65 explaining that one per cent increase in of amount borrowed led to 2.65 per cent increase in overdue amount. The elasticity of coefficient cropping intensity and old debts was -0.42 and 0.58 , respectively.

Table 8

Estimated multiple linear regression model for the medium farmer borrowers

Dependent variable - overdues $(\mathrm{Y})$

Number of farmer borrowers $(\mathrm{N})=26$

\begin{tabular}{|l|l|c|c|c|c|}
\hline S. No. & Explanatory variables & Regression coefficients & Standard Error & $V I F$ & Elasticity coefficients \\
\hline 1. & Intercept $(\mathrm{a})$ & 12635.0383 & 11439.7191 & - & - \\
\hline 2. & Amount borrowed $\left(\mathrm{X}_{3}\right)$ & $0.0844^{* *}$ & 0.0242 & 1.3827 & 2.65 \\
\hline 3. & Cropping intensity $\left(\mathrm{X}_{4}\right)$ & $-0.3111^{*}$ & 0.1431 & 1.1208 & -0.42 \\
\hline 4. & Old debts $\left(\mathrm{X}_{11}\right)$ & $0.4781^{* *}$ & 0.1329 & 1.3727 & 0.58 \\
\hline
\end{tabular}

$>$ Coefficient of determination $\left(\mathrm{R}^{2}\right)$

$-0.7557$

$>$ Adjusted coefficient of determination $\left(\mathrm{R}^{2}\right)-0.7224$

$>$ Coefficient of multiple correlation $(\mathrm{R}) \quad-0.8693$

$>$ 'd' statistics

$-2.3414$

$>$ 'F' value (with 3, 22 d.f.)

$-22.68$

** Significant at $5 \%$ level of significance

* Significant at $10 \%$ level of significance

Regression results for large farmers

For large category of farmers, important factors that affect amount of overdue are gross farm income, amount borrowed, expenditure on family consumption and old debts.
Together they explained 75.83 percent of variation in amount of overdue. The results are presented in Table 5D.16.

Table 9: Estimated multiple linear regression model for the medium cum large farmer borrowers

Dependent variable - overdues $(\mathrm{Y})$

Number of farmer borrowers $(\mathrm{N})=37$

\begin{tabular}{|l|l|c|c|c|c|}
\hline S. No. & Explanatory variables & Regression coefficients & Standard Error & $V I F$ & Elasticity coefficients \\
\hline 1. & Intercept $(\mathrm{a})$ & 1909.3529 & 7678.3057 & - & - \\
\hline 2. & Gross farm income $\left(\mathrm{X}_{1}\right)$ & $-0.0707^{* *}$ & 0.0238 & 1.3471 & -2.74 \\
\hline 3. & Amount borrowed $\left(\mathrm{X}_{3}\right)$ & $0.1031^{* * *}$ & 0.0218 & 1.6036 & 3.04 \\
\hline 4. & Expenditures on family consumption $\left(\mathrm{X}_{8}\right)$ & $0.1007^{*}$ & 0.0489 & 1.5431 & 0.66 \\
\hline 5. & Old debts $\left(\mathrm{X}_{11}\right)$ & $0.4975^{* * *}$ & 0.1127 & 1.5922 & 0.62 \\
\hline
\end{tabular}

$>$ Coefficient of determination $\left(\mathrm{R}^{2}\right)$

$>$ Adjusted coefficient of determination $\left(\mathrm{R}^{2}\right)$

$>$ Coefficient of multiple correlation $(\mathrm{R})$

$>$ 'd' statistics

$>$ ' $\mathrm{F}$ ' value (with 4, 32 d.f.)

*** Significant at $1 \%$ level of significance

** Significant at $5 \%$ level of significance

* Significant at $10 \%$ level of significance

Regression results for large category of farmers indicate that regression coefficient of gross farm income $\left(X_{1}=-0.0707\right)$ was significantly negative at 5 per cent level of significance and the negative sign emphasizes that as the gross farm income increased, farmers repaying capacity improves which in turn led to decline in overdues. The regression coefficient of amount borrowed $\left(\mathrm{X}_{3}=0.1031\right)$ was significant at 1 per cent level of significance and indicated that as higher amount borrowed by the farmer led to higher amount
0.7851

0.8860

1.9295 


\section{International Journal of Science and Research (IJSR) \\ ISSN (Online): 2319-7064}

Index Copernicus Value (2015): 78.96 | Impact Factor (2015): 6.391

explanatory variables was $-2.74,3.04,0.66$ and 0.62 for gross income, amount borrowed, expenditure on family consumption and old debts, respectively.

\section{Conclusion}

In order to assess the efficiency of credit system it is important. The study shows that out of 160 sampled borrowers the extent of repayment, over dues and factors responsible for overdues the total short-term credit borrowed by the sampled farmers in the state of Rajasthan is Rs. 13861.00 per farm and Rs. 3217.84 per hectare. Out of per farm average short-term credit borrowed from the banks 87.77 per cent was repaid by due date and the remaining 12.23 per cent remained as over dues. The total repayable average short term credit increased with an increase in operational holdings on per farm basis but contrary situation was observed on per hectare basis. The information with regard to per farm and per hectare repayable, repaid and overdue of medium-term average bank credit by the due date (up to 30.06.2012) revealed that total medium-term credit borrowed is Rs. 17801.60 per farm and Rs. 2370.23 per hectare. Out of per farm average medium-term credit borrowed from the banks 83.05 per cent was repaid by due date and the remaining 16.95 per cent remained as over dues. Overall analysis emphasizes that per farm repayment performance declined with the increase in size of the operational holdings and semi-medium farm size showed poorest performance among all size groups. The total per farm and per hectare long-term credit borrowed by banks and the category-wise repayment and overdues for sampled farmers in the state of Rajasthan is calculated to be Rs. 70506.50 per farm and Rs. 16408.48 per hectare. Out of per farm average long-term credit borrowed from the banks 74.40 per cent was repaid by due date and the remaining 25.60 per cent remained as overdues. The per farm repayment performance of farmers borrowers decreased with an increase

The total short-term credit borrowed by the sampled farmers in the state of Rajasthan is Rs. 13861.00 per farm and Rs. 3217.84 per hectare. Out of per farm average short-term credit borrowed from the banks 87.77 per cent was repaid by due date and the remaining 12.23 per cent remained as overdues. The total repayable average short term credit increased with an increase in operational holdings on per farm basis but contrary situation was observed on per hectare basis. The information with regard to per farm and per hectare repayable, repaid and overdue of medium-term average bank credit by the due date (up to 30.06.2012) revealed that total medium-term credit borrowed is Rs. 17801.60 per farm and Rs. 2370.23 per hectare. Out of per farm average medium-term credit borrowed from the banks 83.05 per cent was repaid by due date and the remaining 16.95 per cent remained as overdues. Overall analysis emphasizes that per farm repayment performance declined with the increase in size of the operational holdings and semi-medium farm size showed poorest performance among all size groups. The total per farm and per hectare long-term credit borrowed by banks and the category-wise repayment and overdues for sampled farmers in the state of Rajasthan is calculated to be Rs. 70506.50 per farm and Rs. 16408.48 per hectare. Out of per farm average long-term credit borrowed from the banks 74.40 per cent was repaid by due date and the remaining 25.60 per cent remained as overdues. The per farm repayment performance of farmers borrowers decreased with an increase in operational holdings. Nonfarm income, farm income and cropping intensity affected amount of overdue negatively while amount spent on unproductive purposes, old debts, amount borrowed and expenditure on family consumption had positive impact on the amount of overdue of sampled farmers.

Inadequate amount of loan, insufficient time for repayment, lengthy loan process banking agencies, inadequate finances sanctioned by banks to meet the actual requirements, lack of awareness, prevalence of corrupt practices and noncooperation from banking officials in procurement of loan were few reported difficulties by the sampled farmers.

\section{References}

[1] Moorthi, T.V.; Vashist, G.D. and Parmar, Urmil, 1988, "Utilization and overdoes of Co-operative Loans in Himachal Pradesh (A case study Panchrukhi Block, Dist.-Kangra)". Indian Co-operatives Review, 26 (1) 86-94.

[2] Munshi, M.A. and Pandya, D.N., 1985, Utilization pattern of agricultural credit by co-operative societies. Indian Co-operative Review, 23 (2) ; 145-150.

[3] Murthy, H.G.S., Hiremath, G.K. and Khan, H.S.S., 1990, An economic analysis of constrains in financing of production and marketing of bidi tobacco in Karnataka. Financing Agriculture, 22 (3) ; 21-22.

[4] Pandit, A., Pandey, N.K., Lal, B., Chandran, K.P. and Rana, R.K., 2007, Financing agriculture : A study of Bihar and West Bengal potato cultivation. Indian Journal of Agricultural Economics, 62 (3) ; 340-349.

[5] Patel, R.H.; Patel, G.N., Desai, M.M. and Patel, R.M. 1987. A study of Utilization of Farm Credit. Indian Co-operative Review, 25 (1), July, 1987, pp. 93-101.

[6] Patil, S.G. and Angol, Malati, 1989, "Priority Sector Advances by Urban Co-operative Bank : Same Operations and Suggestions". Indian Cooperative Review, 26 (2) ; 131-140.

[7] Prasad, Y.; Eswara, R.; Ramanna and Lalith Achoth, 1991. Analysis of Technology Efficiency of Subsidized credit for Poverty Alleviation in Anantpur, Andhra Pradesh. Indian Journal of Agricultural Economics, 46 (1), Jan, March, pp. 64.

[8] Rajput, A.M. and Verma, A.R., 1998, Flow of institutional credit in agriculture in Indore district of Madhya Pradesh. Indian Journal of Agricultural Economics, 53 (3) ; 512.

[9] Rajput, A.M. and Verma, A.R., 2005. Credit financing of regional rural banks in agricultural sector in Hoshangabad district of Madhya Pradesh. Indian Journal of Agricultural Economics, 60 (3) ; 360-361.

[10] Ramasamy, C. and Meskel, R., 1988, commercial bank lending to agriculture - Some lending issues. Indian Journal of Agricultural Economics, 43 (3) ; 441-442.

[11] Sain, S., 1998, Pattern and performance of different credit agencies in the farming sector of the Punjab economy - an empirical investigation. Indian Journal of Agricultural Economics, 53 (3) ; 513.

\section{Volume 6 Issue 7, July 2017 www.ijsr.net}




\section{International Journal of Science and Research (IJSR) \\ ISSN (Online): 2319-7064}

Index Copernicus Value (2015): 78.96 | Impact Factor (2015): 6.391

[12] Sharma, V.K., 2008, Institutional financing and determinants of agricultural overdues. IUP Journal of Agricultural Economics, 5 (4) ; 67-84.

[13] Shivappa, H., 2005, Agricultural credit utilization pattern and its repayment performance of borrower's of Regional Rural Banks in Karnataka - A case study of Chitradurga Gramina Bank. Indian Journal of Agricultural Economics, 60 (3) ; 366.

[14] Chand, R. and Sidhu, D.S., 1981, Distribution of agricultural credit and concentration of overdues in Punjab. Financing Agriculture, 13 (2) ; 18-20. 